\title{
Exploring Innovative Pedagogy To Deliver Financial Education: A Peer-To-Peer Event With Students
}

\author{
Oscar J. Solis, Virginia Tech, USA
}

\begin{abstract}
An innovative 2015 Financial Education Event utilized collaborative learning, peer-to-peer learning strategies, and multimedia to engage students and deliver financial content. Thirty-three students in a financial counseling class hosted the event for students from a personal finance course as well as the university community. For the event, the financial counseling class conducted research and created six financial infographics that were presented in an openfloor setting on six 70-inch monitors. The six financial topics included budgeting basics, conquering credit, how to be a smart shopper, how to manage student loan debt, kick-starting your first job, and life after college. The financial education event was an opportunity for students to interact and engage in financial dialogue in a fun, enthusiastic, and interactive environment. During this peer-to-peer educational event, students were able to explore, engage, and learn beyond the traditional classroom setting.
\end{abstract}

Keywords: Financial Education; Peer-To Peer; College Students; Collaborative Learning

\section{INTRODUCTION}

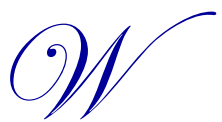

hen considering finances and the future, most college students are not fully versed in how to answer questions related to personal finance. Researchers have documented that many college students have insufficient knowledge of basic financial literacy (Mandell, 2008), and have difficulty understanding budgeting (Henry, Weber, \& Yarbrough, 2001; Gutter \& Copur, 2011) and credit (Joo, Grable, \& Bagwell, 2003; Robb, 2011). To fill this void, financial education is being fused into the college experience at campuses across the U.S. (Supiano 2010). For example, online activities and case studies have previously been used to enhance financial education among upper-level classes (Holland, 2014). Finding additional effective and innovative ways to teach courses in personal finance and basic financial literacy is of importance to meet the growing need for teaching these courses and to identify pedagogy that works for increasingly large-sized financial education classes. The purpose of this article is to highlight methods and techniques used to interactively deliver financial education and raise financial awareness among college students at a large public university.

To introduce this innovative program, the following scenario is provided. Two college students, Samantha and Anthony, discovered how much they did not know and how much information they needed at an innovative financial education event at a major research university. At the event, 33 students from a senior-level financial counseling course hosted 140 students from an introductory personal finance course which included freshmen (7); sophomores (54); juniors (60); and seniors (19). Samantha and Anthony, typical of many college students, stopped by the event to discuss an infographic on the financial realities of life after college - one of six infographics on financial topics that they viewed. They agreed that their pending graduations would mean losing their parents' financial support and assuming the responsibility for all of their own expenses. "Right now," said Samantha, "I am fully dependent on my parents." Anthony echoed those sentiments as they left the interesting and helpful event. 


\section{REVIEW OF LITERATURE}

Understanding how to develop and facilitate a financial education event can offer great benefits to instructors in financial education programs and classrooms. Using collaborative learning, peer-assisted pedagogy, and multimedia, an instructor can maximize classroom learning while improving student engagement (Holland, 2014). Several researchers have studied peer-assisted learning in higher education and healthcare education (Boud, Cohen, \& Sampson, 2014; Colvin, 2015; Damon, 1984; Keimig, 1983; Secomb, 2008). Keimig (1983) found that student competencies can be developed by reaching students in their learning environments, collaboratively designing in-class and extracurricular course components to support student learning and relying on engaging instructors and peereducators to deliver content. In personal finance classes at the college level, student participation, in contrast to the traditional lecture method, is known to improve financial literacy (Peng, Bartholomae, Fox, \& Cravener, 2007; Lai, Kwan, Kadir, Abdullah, \& Yap, 2010). In addition, student engagement through peer financial counseling has also proven effective in enhancing financial literacy (Borden, Lee, Serido, \& Collins, 2008; Maurer \& Lee, 2011). Students who are engaged in activities rather than pedagogies of reading or note-taking tend to retain and use more financial information. The interactive event explained in this study combines student participation and peer-to-peer counseling or peer-assisted learning.

As noted by Secomb (2008), collaboration among peers plays an important role in fostering communication skills, presentation skills, decision-making skills, leadership skills, teamwork, confidence and respect for peers. Collaboration between peers provides an academic environment that promotes learning and creative thinking (Damon, 1984). The development of the financial education event served as an opportunity for financial counseling students to collaborate and hone their communication skills and work to together as a team. Damon (1984) stated the collaboration between peers forms an exchange that allows students to learn basic concepts. The financial education event was an ideal environment for the personal finance students to learn basic financial concepts as well as challenging and difficult financial concepts.

In Bloom's taxonomy of learning, remembering, understanding, and application are considered to be the lowest levels of learning (Bloom, Engelhart, Hill, \& Krathwohl, 1956; Krathwohl, 2002). With the development and administering of the financial education event these lower levels of Bloom's learning taxonomy were completed before, during and after class by the financial counseling students. Students researched financial concepts through the internet, books, journal articles, and videos. Using Bloom's taxonomy as a reference, learning at higher levels such as application, analysis and synthesis were enhanced by students researching and discussing financial topics with their groups and organizing the ideas and designing the infographics and experiencing in-class active learning exercises.

Peer-to-peer learning promotes learning outcomes. Boud et al. (2014) highlight five commonly shared learning outcomes in higher education: (1) working with others, (2) critical enquiry and reflection, (3) communication and articulation of knowledge, understanding and skills, (4) managing learning and how to learn, and (5) self- and peerassessment. The learning outcomes for the financial counseling class were to collaborate through teamwork, become a member of a learning community, communicate and articulate knowledge of financial concepts. Peer learning activities require students to discover strategies to create a learning environment and often prompts student to be aware of their own learning skills (Boud et al., 2014). Additional outcomes were for students to communicate their understanding of financial concepts to their peers.

Across the country, college and university administrators have expressed concern over students' lack of financial literacy and their problematic financial behaviors (Kezar, 2009; Supiano, 2009). Colleges and universities are finding ways to address the concerns by incorporating financial education into the college experience (Supiano, 2010) through financial workshops, seminars, and courses. The ion mission has also weighed in on the importance of financial education in colleges and universities, stating that "there is little research on successful methods for financial education" (2006, p. xi). To address this situation at our university, we decided to incorporate a financial education event in addition to the personal finance class. The financial education event was the first financial education event to be facilitated by students, include peer-to-peer learning, and use a unique multimedia learning method such as infographics. In addition, this study contributes to financial education of research on peer-to-peer learning through 
the use of infographics. Students conducted research on the selected financial topics and created materials and activities that provided additional learning opportunities for their peers.

\section{METHODS}

The financial education event consisted of a development aspect in preparation to the event, the conduct of the event, and the post-event analysis Figure 1. The instructor of two financial education classes directed the preparation, delivery, and analysis of the event. In total, more than 180 students participated in some aspect of the event. University-approved course content for the two classes was considered and used as a guideline for the content of the event, but specific content was directed by the students. The event was held April 14, 2015 from 9:30 to 11 am on the campus of a large university.

Figure 1. Conceptual Model for the Financial Education Event

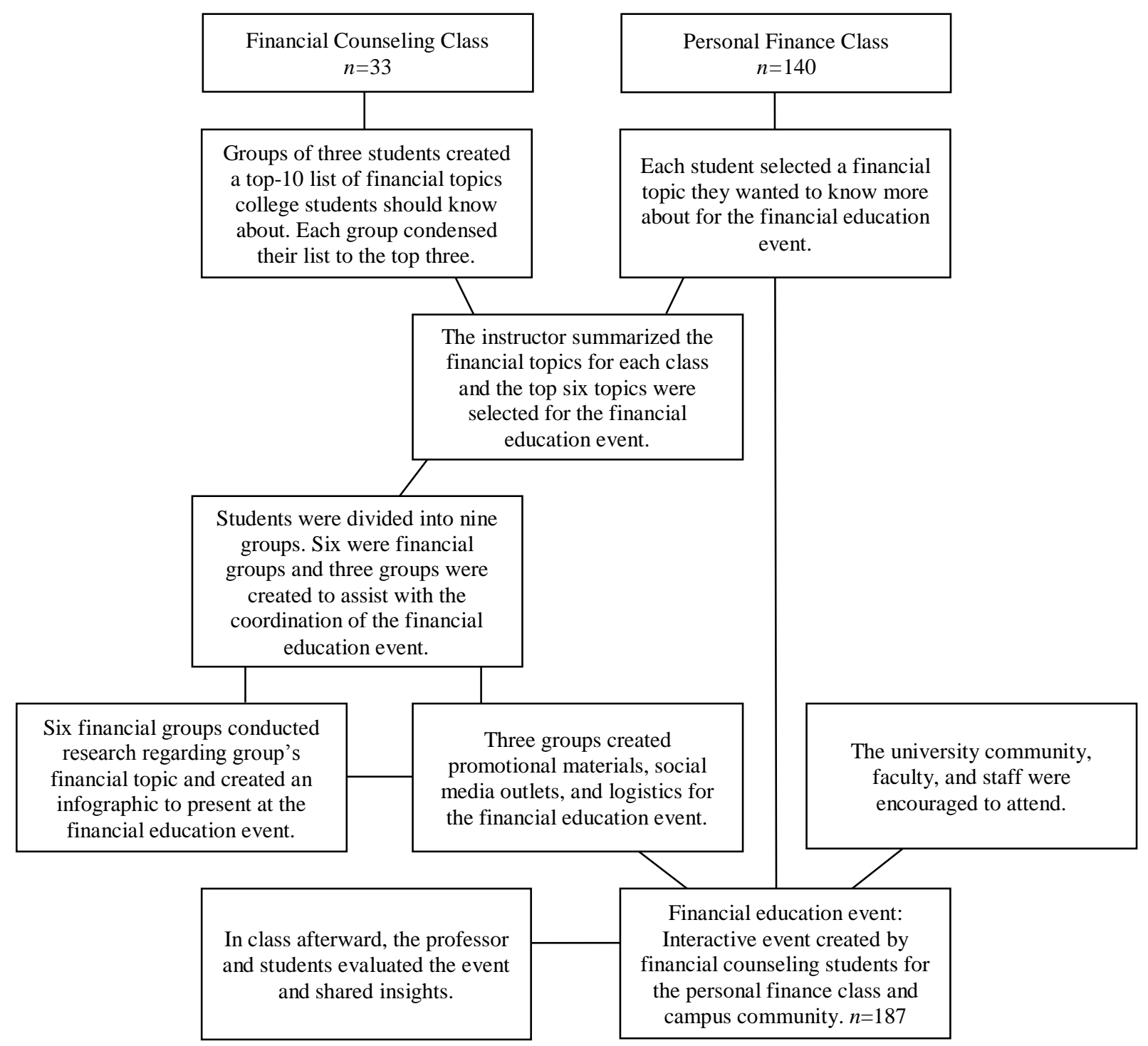




\section{Developing the Financial Education Event}

In preparation for the event, two methods were used to identify the financial topics to include in the event. Both the upper-level financial counseling class and the lower-level personal finance class were polled for financial topics of interest for them as college students (see Figure 1). Each class was presented with a separate method to identify the pertinent financial topics. Using a collaborative learning method, the financial counseling students (upper-level students) were divided into groups of three to create a top-10 list of financial topics that they thought their collegiate peers should know. Once each group's list was completed, the groups identified and ranked the top three financial topics on their respective lists. The personal finance students (lower-level students) participated in a separate in-class activity, with each student identifying one financial topic of interest. To finalize the topics for the financial education event, the instructor tallied and compared both classes' submissions and identified the top six topics. The six financial topics included budgeting basics, conquering credit, how to be a smart shopper, how to manage student-loan debt, kick-starting your first job, and life after college.

Once the topics were identified and confirmed, the financial counseling students were divided into nine groups: six financial groups of four and three logistical groups of three. Each financial group was assigned one of the six topics and conducted research and created a digital infographic on their topic, while the three logistical groups completed assignments related to social media, public relations, and event logistics to prepare for the delivery of the actual event as indicated in Figure 1.

The financial counseling class allocated 30 minutes of class time in seven classes to complete various task for the financial education event. Students spent time outside of class researching their respective topics via the Internet and university libraries. The amount of time varied from 30 minutes to an hour and a half per week. The outside class time depended on the task at hand and how well the group worked together and how efficiently the students utilized their time. The tasks also included a brainstorming activity to identify financial topics, discussing financial topics, group activities related to creating infographics, developing promotional materials, and evaluating the infographics as a class. Aside from supervising students during class, the instructor spent 30 minutes meeting with library administrators to solidify the campus venue for the financial education event.

\section{Delivering the Financial Education Event}

The structure of the event was based on the value of incorporating active, collaborative, and peer-assisted learning, through which students could serve the internal academic community. The event was held in a multimedia room in the university's library, providing an open space for showing digital information and providing room for one-to-one or peer-to-group explanations. Displayed on six monitors, the infographics, developed by the financial counseling class, offered facts, statistics, and helpful tips. The 70-inch monitors in the multimedia room allowed students to engage in financial dialogue in an interactive environment. Students could stroll from display to display, picking topics of interest, reading the infographics, and asking questions of the upper-level student groups who were at each display.

The personal finance students were able to attend the event during their regular class time, ask the financial counseling students questions, and participate actively in various activities, such as using money management websites and various debt calculators displayed on computers stationed next to each infographic. Through this peer-to-peer interaction, the students taught each other the concepts, with the financial counseling students acting as peer educators. Researching topics, preparing infographics, and explaining the information to other students at the event helped solidify the information for the financial counseling students. In addition, friends of students, students in other financial education classes, and anyone in the library during the event were welcome to participate.

At the event, the personal finance students also participated in an interactive financial activity in which they completed a form with a combination of fill-in-the-blank, multiple-choice, and short-answer questions about the infographics. Four variations of the form were created to ensure that students were viewing all of the infographics and to minimize the sharing of answers. All versions of the form included eight questions (questions one through six were different "knowledge" questions and questions seven and eight were the same on all four versions). Question seven asked 
students which financial infographic they were most interested in viewing and question eight asked students which financial topics should be included in future financial education events. Each student received one of the four versions. Students were encouraged to interact with financial counseling students and ask questions about the infographics that would assist students with answering the questions. During this time the financial counseling students were able to teach students about their financial topics and answer questions. This activity was an empowering moment for the financial counseling students because they were teaching their peers and applying the financial information to their peers' lives. The activity was not formally administered for a grade and was used as a participation activity and way to create peer-to-peer learning opportunities among students. This activity also provided the instructor with feedback about how well the students had learned the information and reiterated specific concepts deemed by the financial counseling students as important for their peers. In addition to the infographics and financial activity, an additional 90-inch monitor displayed a live-stream social media feed on which the participating students posted pictures and comments, making the event accessible to those who could not attend in person.

\section{Evaluating the Financial Education Event}

To evaluate the event, the instructor and the students in both classes spent time in reflection on the event. In the class period following the event, the instructor asked for student feedback about the event. The verbal feedback included assessments about the organization of the event, positives and negatives about the event, usefulness of the financial information, most interesting financial topics, the design of the infographics, and the multimedia aspect of the event. In addition, the instructor reviewed the social media feed for student comments. Benefits and drawbacks for the event are discussed in the following sections.

\section{Benefits and Drawbacks for the Financial Counseling Class}

The peer-assisted learning, applicable to audiences of all sorts, proved to be mutually beneficial as students shared knowledge and experiences. The instructor placed a heavy emphasis on students helping each other acquire the skills needed to make informed financial decisions. To prepare for the event, the financial counseling students conducted research, created visual methods to convey information, and offered interactive activities such as online debt calculators for their peers. The tasks reinforced leadership development, public-speaking skills, and teamwork. The one drawback for the event was the time spent planning the event instead of learning financial content; however, students who wish to pursue careers in financial services will often need to host events and other consumer-focused activities. Students said that they thought it was worth the time and the effort. Immediately after the event, a financial counseling student said, "This (event) really made the information seem important to me and made me want to know more to help more people." Thus, the financial counseling students were able to gain more experience in communicating financial topics and were able to articulate their understanding of financial topics through an innovative media, infographics. Ultimately, the students experienced both lower and higher levels of learning (Bloom et al., 1956).

\section{Benefits and Drawbacks for the Personal Finance Class}

For personal finance students, meanwhile, the event resulted in higher levels of financial literacy for their daily lives and, importantly, greater retention of the financial lessons. Students explored fundamental financial concepts in the infographics and asked questions of their peers. Students were able to move beyond mere financial definitions and were able to learn how the financial topics such as credit, budgeting, student loans, investments, and basic money management might apply to and impact their lives. For example, the student group that created the credit card infographic included a credit card debt calculator below the infographic and students were able to insert a hypothetical credit card debt amount and interest rate to find out how long the borrower would take to pay off the debt. This was an eye-opening experience for many students. Students also commented that they enjoyed asking other students their financial questions and felt more comfortable revealing their concerns about financial issues to the upper-level students, in contrast to their discomfort with asking questions in a large classroom. No drawbacks were noted for the event, especially because the event was scheduled during the regular class time. 


\section{Overall Evaluation of the Financial Education Event with Suggestions for the Future}

The event was considered to be a success by the instructor and students. The increases in learning and awareness demonstrated by the students validated the class time allocated for the event. For the upper-level students, practicing financial counseling skills in a real-life event helped cement the financial information, while learning from peers helped engage the lower-level students. In addition, the event triggered interest in financial education for the broader university community and provided visibility for the financial education courses.

To enhance the event for its next iteration, several items were noted as important. The instructor would pursue more campus-wide advertising of the event to attract a wider audience. The instructor also would continue to utilize technological resources and expand the topics presented. The event itself would include one or two topics catered to faculty and staff, such as employee benefits and retirement and savings strategies. Payday loans, title loans, and refund anticipatory loans would also be options. The responses in Appendix A include future financial topics recommended by personal finance students. Additionally, instructors interested in developing and administering a similar financial education event will expose students and the university community to pertinent financial information that will benefit those involved for a lifetime.

\section{CONCLUSION}

The author's primary motivation for creating the collaborative event was to support the quality of undergraduate learning in a large class, where active learning methods are critical to student learning. A second motivation was to meet students' requests for more interactive learning in large class settings, as revealed by student perception surveys and anecdotal evidence from prior semesters. The financial education event met both of these goals.

Active learning occurs when instructors connect relevant material to students' lives. For financial professionals who are seeking inventive ways to reach their various audiences, the event utilized three key teaching methodscollaboration, peer-assisted learning, and the use of multimedia - that hold tremendous potential for engaging students and enhancing their knowledge retention. In addition, the event aimed to help students integrate information and understand the connections between new ideas and examples. During this peer-assisted educational event, in a setting apart from the traditional classroom, students were able to explore, engage, and learn with their peers. These techniques, which proved effective in an academic environment, may work just as well for a financial counselor's outreach event or financial educator's workshop in a community setting. For these outreach events or workshops, students from nearby colleges or high schools could participate through service-learning projects, offering to help the financial educators and counselors create and present the infographics. This format has the potential to integrate several stakeholders in the preparation and delivery of information.

\section{AUTHOR BIOGRAPHY}

Oscar J. Solis is a Collegiate Associate Professor of Consumer Studies (with emphasis in Consumer Finance) in the Department of Apparel, Housing, and Resource Management at Virginia Tech in Blacksburg, Virginia. Recent research projects include the exploration of pedagogical strategies for small and large classes and financial education for college students. His research has been published in the Journal of Effective Teaching and the Journal of Personal Finance.

\section{REFERENCES}

Bloom, B. S., Engelhart, M. D., Hill, W. H., \& Krathwohl, D. R. (1956). Taxonomy of educational objectives: The classification of educational goals. Handbook I: Cognitive domain. New York. David McKay Company.

Borden, L. M., Lee, S., Serido, J., \& Collins, D. (2008). Changing college students' financial knowledge, attitudes, and behavior through seminar participation. Journal of Family and Economic Issues, 29, 23-40.

Boud, D., Cohen, R., \& Sampson, J. (Eds.). (2014). Peer learning in higher education: Learning from and with each other. Routledge.

Colvin, J. W. (2015). Peer mentoring and tutoring in higher education. In Exploring Learning \& Teaching in Higher Education. pp. 207-229. Springer Berlin Heidelberg.

Copyright by author(s); $\underline{\text { CC-BY }}$ 
Damon, W. (1984). Peer education: The untapped potential. Journal of Applied Developmental Psychology, 5(4), $331-343$.

Financial Literacy and Education Commission. (2006). Taking ownership of the future: The national strategy for financial literacy. U.S. Department of Treasury. Washington D.C., Author.

Gutter, M., \& Copur, Z. (2011). Financial behaviors and financial well-being of college students: Evidence from a national survey. Journal of Family and Economic Issues, 32(4), 699-714.

Henry, R. A., Weber, J. G., \& Yarbrough, D. (2001). Money management practices of college students. College Student Journal, $35,244-247$.

Holland, L. C. (2014). Student online presentations and peer evaluations in a face-to-face case class. Journal of Financial Education, 40, 45-67.

Joo, S., Grable, J. E., \& Bagwell, D. C. (2003). Credit card attitudes and behaviors of college students. College Student Journal, $37,405-420$.

Keimig, R. T. (1983). Raising academic standards: A guide to learning improvement. ASHE-ERIC/Higher Education Research Report No. 4, 1983.

Kezar, A. (2009). Increasing access for low-income students and making financial education a priority for higher education. Liberal Education, 95, 38-43.

Krathwohl, D. R. (2002). A revision of Bloom's taxonomy: An overview. Theory into Practice, 41(4), $212-218$.

Lai, M. M., Kwan, J. H., Kadir, H. A., Abdullah, M., \& Yap, V. C. (2009). Effectiveness, teaching, and assessments: Survey evidence from finance courses. Journal of Education for Business, 85(1), 21-29.

Mandell, L. (2008). The financial literacy of young American adults. Washington, DC: The Jump\$tart Coalition for Financial Literacy.

Maurer, T. W., \& Lee, S. A. (2011). Financial education with college students: Comparing peer-led and traditional classroom instruction. Journal of Family and Economic Issues, 32(4), 680-689.

Peng, T. C. M., Bartholomae, S., Fox, J. J., \& Cravener, G. (2007). The impact of personal finance education delivered in high school and college courses. Journal of Family and Economic Issues, 28(2), 265-284.

Robb, C. A. (2011). Financial knowledge and credit card behavior of college students. Journal of Family and Economic Issues, 32, 690-698.

Secomb, J. (2008). A systematic review of peer teaching and learning in clinical education. Journal of Clinical Nursing, 17(6), 703-716.

Supiano, B. (2009). To get this grant, students have to take 'personal finances 101'. The Chronicle of Higher Education. Retrieved from http://www.chronicle.com/

Supiano, B. (2010). Does financial lit change student behavior? One researcher says 'yes and no'. The Chronicle of Higher Education. Retrieved from http://www.chronicle.com/ 


\section{APPENDIX A}

Responses from personal finance students to "What other financial topics do you think should be included in the (future) Financial Literacy Event?"

\section{Future Financial Topics}

- Apps for Money Management

- Banking for College Students (Checking and Savings Accounts)

- Buying an Automobile

- Buying a Home (Helpful Tips)

- Different Types of Insurance

- Different Types of IRAs

- Financing a Wedding

- Health Insurance for College Students

- How to Save as a College Student

- Investing Basics (Stocks and Bonds)

- Managing Taxes

- Paying for Graduate School (Assistantships)

- Renting versus Buying (Automobile and Housing)

- Retirement Saving and Planning

- Scholarships and Grants

- Starting Salaries for Variety of Career Paths

- Way to Increase Income in College 